\title{
A systematic review of implicit bias in health care: A call for intersectionality
}

\author{
Oluwabunmi Ogungbe ${ }^{1}$, Amal K. Mitra ${ }^{1}$, Joni K. Roberts ${ }^{2}$ \\ ${ }^{I}$ Department of Epidemiology and Biostatistics, School of Public Health, Jackson State University, \\ Jackson, Mississippi 39213, USA; ${ }^{2}$ Department of Behavioral and Environmental Health, School of Public \\ Health, Jackson State University, Jackson, Mississippi 39213, USA.
}

\begin{abstract}
Background and objectives: Health disparities are a growing concern in health care. Research provides ample evidence of bias in patient care and mistrust between patient and providers in ways that could perpetuate health care disparities. This study aimed to review existing literature on implicit bias (or unconscious bias) in healthcare settings and determine studies that have considered adverse effects of bias of more than one domain of social identity (e.g., race and gender bias) in health care.
\end{abstract}

Methods: This is a systematic review of articles using databases such as EBSCO, Embase, CINAHL, COCHRANE, Google Scholar, PsychINFO, Pub Med, and Web of Science. Search terms included implicit bias, unconscious bias, healthcare, and public health. The inclusion criteria included studies that assessed implicit bias in a healthcare setting, written in English, and published from 1997-2018.

Results: Thirty-five articles met the selection criteria - 15 of which examined race implicit bias, ten examined weight bias, four assessed race and social class, two examined sexual orientation, two focused on mental illness, one measured race and sexual orientation, and another investigated age bias.

Conclusions: Studies that measured more than one domain of social identity of an individual did so separately without investigating how the domains overlapped. Implicit Association Test (IAT) is a widely used psychological test which is used to determine existence of an implicit bias in an individual. However, this study did not find any use of an instrument that could assess implicit bias toward multiple domains of social identities. Because of possible multiplicative effects of several biases affecting a single entity, this study suggests the importance of developing a tool in measuring intersectionality of biases.

IMC J Med Sci 2019; 13(1): 005. EPub date: 13 March 2019

\section{Introduction}

Gender inequality is a major social issue which may adversely affect women's health in developing countries. Similarly, race, gender, sexual orientation, body weight, social class, nationality, and religion are common social identities where discrimination or bias exists in many developing and developed societies. The combined adverse effects of implicit bias (or unconscious bias) towards persons with intersecting social identities are stronger than the separate effects of a single identity. An intersectionality framework is a useful approach to understanding the complexities of health disparities and inequalities.

Intersectionality is a theoretical framework for understanding how several social identities such as 
race, gender, socioeconomic status, sexual orientation, disability etc., intersect on a micro level of individual experience to show interlocking systems of privilege and oppression (i.e., racism, sexism, heterosexism, classism, etc.) at the macro socialstructural level $[1,2]$. The term 'intersectionality' was first coined by Kimberlé Crenshaw in 1989. Crenshaw in her 1989 essay "Demarginalizing the Intersection of Race and Sex: A Black Feminist Critique of Antidiscrimination Doctrine, Feminist Theory, and Antiracist Politics," described the understandings of race and sex/gender, by outlining marginalization of Black women from the discourse of White feminists and racism [3-5].

Social identities can be influenced by implicit bias, which is the unconscious negative attitude against individuals. Implicit bias resides in the subconscious level and does not require any endorsement from the perceiver. For instance, a person's skin color or accent silently exerts its influence on perception, memory, and behavior, and hence controlling implicit bias is not in any way straightforward [6-8]. The existence of implicit bias can be measured by the Implicit Association Test (IAT), a computerbased measure in which the strength of association is determined by a respondent's speed in sorting items under the concepts provided [9]. This test measures individual items of bias related to race, gender, region, sexual orientation, age, weight, disability, etc.

In the United States, the progress made in reducing implicit attitudes towards race and gender seem to have occurred at a surface level [9]. Such biases are well documented resulting in health disparities, inequities, and inequalities $[6,10]-$ all focus areas of health care [7]. Intersectionality has been widely studied in law, psychology and gender studies, but is scarce in mainstream public health research $[11,12]$. Similar to intersectionality, the hypothesis of double jeopardy posits that when individuals, (especially women), belong to two or more subordinated groups, the disadvantage they face is added or multiplied. A common example is being a woman (gender bias) and being of color (racial bias). Chappell and Havens (2016) described this as the combined adverse effects of occupying two stigmatized statuses as being more significant than occupying each status separately [13]. Double jeopardy and intersectionality were confirmed in the empirical study by Williams (2014) [11]. The study also noted that biases experienced by women differed not only by race but within race, such that women of color have experiences of discrimination that are different from other women of the same race [11]

In contexts such as politics and employment, people's behavior and decision making are greatly influenced by race and gender. The intersectionality of race and gender usually results in a multiplicative predictive value [14]. The presumption of intersectionality is not that all intersecting identities are equally disadvantageous. Instead, the theory considers how the low and high status of social identities multiplies to result in disparity. An intersectionality framework is useful for understanding the complexities of implicit biases and its result in health disparities and inequalities [12]. Therefore, the purpose of this study was to evaluate the literature on implicit bias in healthcare settings and determine whether the literature reflect studies that have considered the multiplicative effects of individuals when assessing implicit bias.

\section{Methods}

\section{Search Strategy}

Using recommendations from the Preferred Reporting Items for Systematic Reviews and Meta-Analyses (PRISMA) [15], a comprehensive literature search was conducted from May 2017 to December 2018 of the databases such as EBSCO, Embase, CINAHL, COCHRANE, Google Scholar, PsychINFO, Pub Med, and Web of Science from the years $1997-$ 2018 to capture studies investigating implicit bias. Studies were eligible for inclusion if they met the following criteria: 1) published in years 19972018; 2) assessed implicit bias in a healthcare setting; 3) the study population being patients or providers, and 4) the articles written in English. Dissertations were eligible, but editorials, responses, and commentaries were excluded. All experimental and quasi-experimental designs were included along with papers reporting any intervention used to reduce bias in a health setting.

\section{Data Extraction}

Of the 2,267 research articles identified through database searching (Figure 1), 1,952 research articles were screened after removing duplicates. 
Next step of screening was to remove articles addressing implicit bias in non-health related fields and those which did not yield full articles $(n=$ $1,868)$. The third step of screening was to exclude articles published before $1997(n=20)$, editorial or short commentary $(n=11)$, and those which did not meet other inclusion criteria $(n=18)$. This screening process yielded a total of 35 studies for final review.

\section{Measurement Tools of Intersectionality \\ Quantitative methods}

A number of statistical methods have been proposed for testing intersectionality. These are: 1) The Hierarchical Classes Analysis (HICLAS) in which subgroup differences are examined [16]; 2) Crosstabulation which was used in a study by Covarrubias (2011) [17]; and 3) Logistic Regression has also been used in a number of studies, especially with an addition of the multiplicative interaction term $[18,19]$, as well as by creating pattern of association in multiple domains of implicit bias using Latent Class Analysis [20]. Some of these methods are based on the propositions of Hancock (2007) and McCall (2005) [21,22]. McCall (2005) described three possible methods to measure intersectionality quantitatively: Anti-categorical Complexity - this approach sees categories as divisions which were socially constructed by people but not based on reality; Intra-categorical complexity -here, categories are not rejected, they are not made the central point; and Inter-categorical complexity - this approach uses categories, but the focus is on the changing relationships between the different identities [22,23].

\section{Qualitative methods}

Methods in qualitative research such as community participatory action research and ethnography

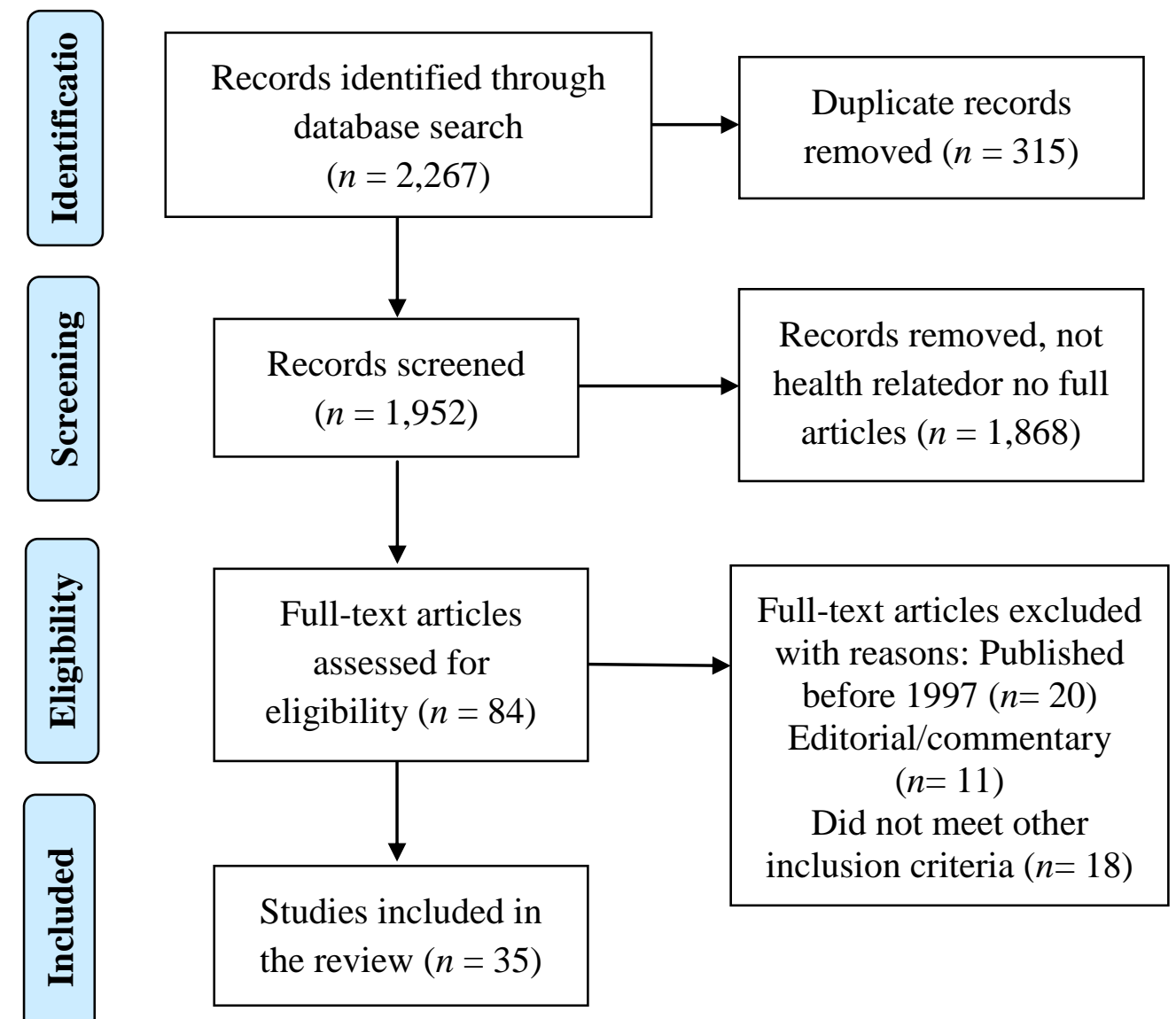

Fig-1. PRISMA diagram 
(interviews and case studies) are well suited methods for conducting intersectionality research [24]. The intersectionality-informed qualitative research primer written by Hunting (2014) provides a comprehensive tool kit for qualitative research methods of intersectionality of social identities. Community participatory action research is useful in that the targeted population directly inform and dictate the direction of the research as well as appropriate interventions. Interviews and case studies are used to explore the intricacies of intersecting identities, and the effects on the lives of individuals [23,24].

\section{Results}

In this review, more than half of the studies (19 of $35,54 \%$ ) focused on race/ethnicity implicit bias, followed by weight or fat-bias (10 of 35, 29\%), and race and social class bias (4 of 35, 11\%). Only $14 \%$ (5 of 35) of the studies measured more than one domain of implicit bias such as race and social class bias, and race and sexual orientation. Two studies reported bias related to mental illnesses, and two reported weight bias alone (Figure 2).

Detailed information including the type of implicit bias, study population, aim of the study, and major findings of the 35 selected studies are presented in Table 1. Majority of the studies reported the presence of moderate to strong implicit bias among the participants. Twelve studies found strong evidence of implicit bias favoring White Americans [25-33], while two studies found weak to moderate evidence of race bias [34,35]. Green et al (2007) found implicit stereotypes of African Americans as less cooperative with medical procedures [10] Some studies examined the relationship between clinician's implicit bias and the quality of the provider-patient relationship [27,31,32,36,37].

\section{Race \& Social Class}

Cooper et al (2012) investigated the link between clinicians' unconscious attitudes concerning race with visit communication and patient ratings of care. This study found an association between implicit racial bias and markers of poor visit communication and poor ratings of care, especially in Black patients [36]. Three studies found evidence of implicit bias but found no evidence that it affects clinician's provision of care or that it predicts treatment recommendations to minority patients [27,32,34]. Similarly, two studies that measured race and social class implicit bias found that their participants had an implicit preference for White persons and for those in the upper social class [30,31]. Two others showed participants IAT scores that were significantly associated with clinical decision making $[38,39]$.

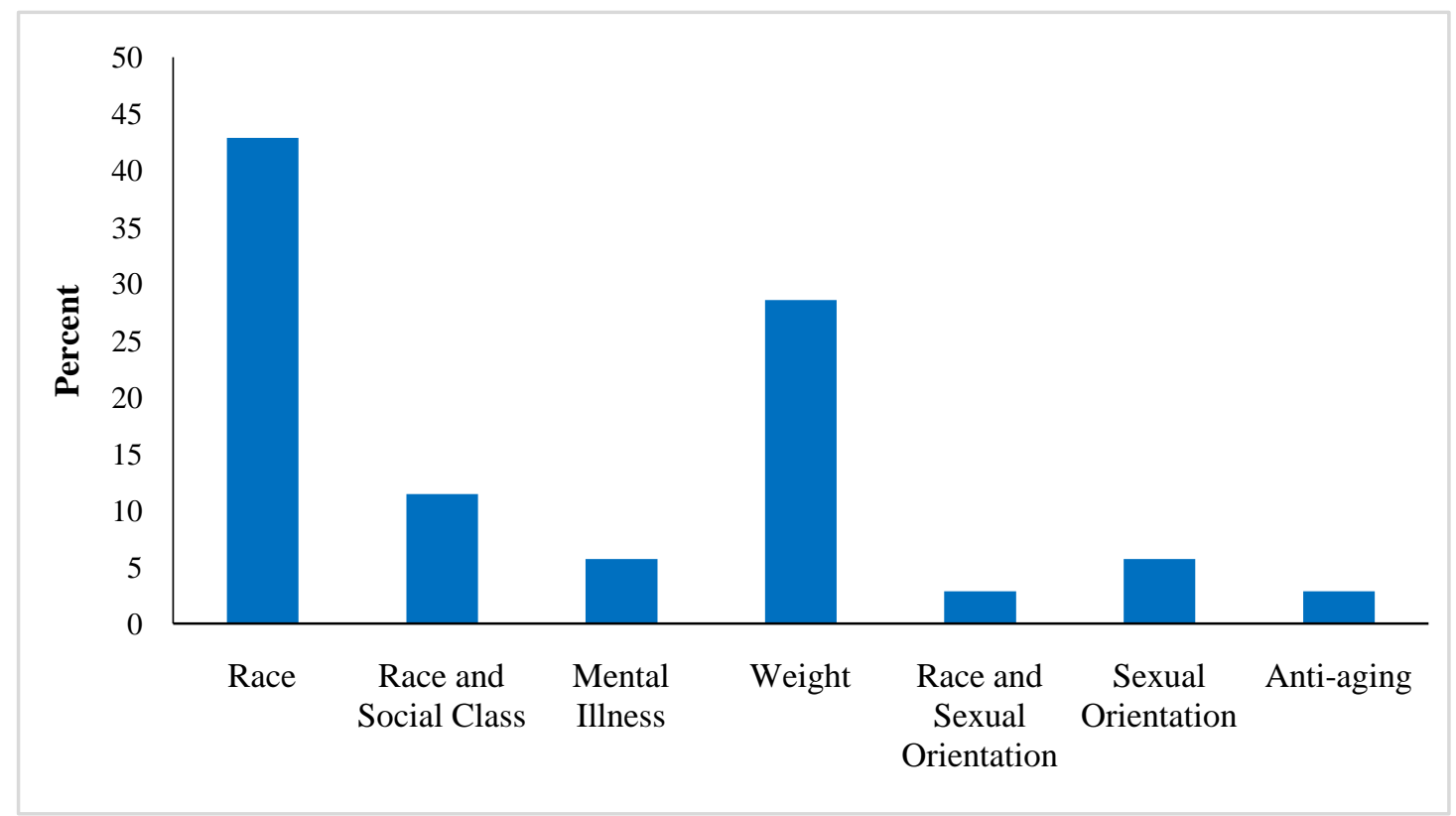

Fig-2. Categories (percent) of implicit bias identified in this study $(n=35)$ 
Table-1: Type of implicit bias, study population, adverse effects of bias, and major findings of 35 studies

\begin{tabular}{|c|c|c|c|c|}
\hline $\begin{array}{l}\text { Author(s) } \\
\text { [Reference] }\end{array}$ & $\begin{array}{c}\text { Type of } \\
\text { implicit bias } \\
\text { measured }\end{array}$ & $\begin{array}{l}\text { Study population; } \\
\text { Aim of the study }\end{array}$ & $\begin{array}{l}\text { Bias affected } \\
\text { health } \\
\text { outcome }\end{array}$ & Major findings \\
\hline $\begin{array}{l}\text { Boysen \& } \\
\text { Vogel } 2008 \\
{[2]}\end{array}$ & $\begin{array}{l}\text { Racial and } \\
\text { sexual } \\
\text { orientation } \\
\text { bias }\end{array}$ & $\begin{array}{l}105 \text { Counselor Trainees were assessed for } \\
\text { implicit bias toward African Americans, } \\
\text { lesbians and gay men and for self-reported } \\
\text { multicultural competency. }\end{array}$ & Yes & $\begin{array}{l}\text { Implicit bias existed among Counselor Trainees } \\
\text { despite high self-reported multicultural } \\
\text { competency. }\end{array}$ \\
\hline $\begin{array}{l}\text { Green et al. } \\
2007[10]\end{array}$ & $\begin{array}{l}\text { Racial implicit } \\
\text { bias }\end{array}$ & $\begin{array}{l}\text { Patients with acute coronary disease; } \\
\text { Physicians' IAT measured to predict their } \\
\text { clinical decision }(n=287)\end{array}$ & Yes & $\begin{array}{l}\text { IATs revealed implicit preference favoring } \\
\text { Whites; Blacks less cooperative with medical } \\
\text { procedures. White MDs more likely to treat } \\
\text { White patients. }\end{array}$ \\
\hline $\begin{array}{l}\text { Sabin et al. } \\
2009[16]\end{array}$ & $\begin{array}{l}\text { Racial implicit } \\
\text { bias }\end{array}$ & $\begin{array}{l}\text { To measure doctors' }(n=2,535) \text { implicit } \\
\text { preference for patients by race. }\end{array}$ & Yes & $\begin{array}{l}\text { Strength of implicit bias exceeded self-report } \\
\text { among all MDs except Black MDs. Women } \\
\text { showed less implicit bias than men. }\end{array}$ \\
\hline $\begin{array}{l}\text { Puumala et } \\
\text { al. } 2016[26]\end{array}$ & $\begin{array}{l}\text { Racial implicit } \\
\text { bias }\end{array}$ & $\begin{array}{l}154 \text { emergency care providers. To assess both } \\
\text { implicit and explicit racial bias and examine } \\
\text { their relationship with clinical care. }\end{array}$ & No & $\begin{array}{l}84 \% \text { of providers had an implicit preference for } \\
\text { non-Hispanic White adults or children. Except } \\
\text { for one study, no association between explicit } \\
\text { bias or clinical vignettes and implicit bias. }\end{array}$ \\
\hline $\begin{array}{l}\text { Oliver et al. } \\
2014 \text { [27] }\end{array}$ & $\begin{array}{l}\text { Racial implicit } \\
\text { bias }\end{array}$ & $\begin{array}{l}543 \text { family and internal medicine physicians. } \\
\text { To evaluate whether the magnitude of implicit } \\
\text { racial bias predicts physician recommendation } \\
\text { of total knee replacement for black and white } \\
\text { patients with osteoarthritis. }\end{array}$ & No & $\begin{array}{l}\text { Participants had a strong implicit preference for } \\
\text { Whites over Blacks, but this did not predict } \\
\text { treatment recommendations. }\end{array}$ \\
\hline $\begin{array}{l}\text { Moskowitz et } \\
\text { al. } 2012 \text { [28] }\end{array}$ & $\begin{array}{l}\text { Racial implicit } \\
\text { bias }\end{array}$ & $\begin{array}{l}\text { To examine whether stereotypes are implicitly } \\
\text { activated in physicians }(n=27) \text {. }\end{array}$ & Yes & $\begin{array}{l}\text { Physicians stereotype certain diseases with } \\
\text { Blacks. This suggests that diagnoses and } \\
\text { treatment of Black patients may be biased. }\end{array}$ \\
\hline $\begin{array}{l}\text { Hausmann et } \\
\text { al. } 2015 \text { [29] }\end{array}$ & $\begin{array}{l}\text { Racial implicit } \\
\text { bias }\end{array}$ & $\begin{array}{l}14 \text { physicians and } 162 \text { patients with spinal cord } \\
\text { injury (SCI). To examine implicit racial bias of } \\
\text { physicians and its association with functioning } \\
\text { and wellbeing for individuals with SCI. }\end{array}$ & Yes & $\begin{array}{l}\text { Physicians had a strong pro-white/anti-black } \\
\text { bias. Greater physician bias was associated with } \\
\text { disability among individuals with SCI. }\end{array}$ \\
\hline $\begin{array}{l}\text { Haider et al. } \\
2011[30]\end{array}$ & $\begin{array}{l}\text { Racial and } \\
\text { social class } \\
\text { bias }\end{array}$ & $\begin{array}{l}202 \text { medical students. To estimate unconscious } \\
\text { race and social class bias among first-year } \\
\text { medical students and investigate its relationship } \\
\text { with assessments made during clinical } \\
\text { vignettes. }\end{array}$ & No & $\begin{array}{l}69 \% \text { of participants had IAT scores showing an } \\
\text { implicit preference for White persons, and } 86 \% \\
\text { for those in the upper class. No association } \\
\text { existed between implicit preferences and the } \\
\text { vignettes-based clinical assessments. }\end{array}$ \\
\hline
\end{tabular}




\begin{tabular}{|c|c|c|c|c|}
\hline $\begin{array}{l}\text { Haider et al. } \\
2014[31]\end{array}$ & $\begin{array}{l}\text { Racial and } \\
\text { social class } \\
\text { bias }\end{array}$ & $\begin{array}{l}\text { To determine if unconscious race and class } \\
\text { biases exist specifically among trauma/acute } \\
\text { care surgeons and }(n=248) \text {; if so, whether } \\
\text { those biases impact surgeons' clinical decision } \\
\text { making. }\end{array}$ & No & $\begin{array}{l}74 \% \text { of the participants had IAT scores } \\
\text { demonstrating an unconscious preference toward } \\
\text { White persons; } 91 \% \text { demonstrated an implicit } \\
\text { preference toward upper social class persons. } \\
\text { These biases were not statistically significantly } \\
\text { associated with clinical decision making. }\end{array}$ \\
\hline $\begin{array}{l}\text { Blair et al. } \\
2014 \text { [32] }\end{array}$ & $\begin{array}{l}\text { Racial/ethnic } \\
\text { implicit bias }\end{array}$ & $\begin{array}{l}138 \text { primary care physicians and } 4,795 \text { patients } \\
\text { with hypertension. To determine if clinicians' } \\
\text { implicit ethnic or racial bias is associated with } \\
\text { treatment for hypertension among Black and } \\
\text { Latino patients, relative to White patients. }\end{array}$ & No & $\begin{array}{l}\text { Implicit bias did not affect clinicians' provision } \\
\text { of care to their minority patients, nor did it } \\
\text { affect the patients' outcomes. }\end{array}$ \\
\hline $\begin{array}{l}\text { Schaa et al. } \\
2015 \text { [33] }\end{array}$ & $\begin{array}{l}\text { Racial implicit } \\
\text { bias }\end{array}$ & $\begin{array}{l}67 \text { genetic counselors. To explore the } \\
\text { relationship between genetic counselors' } \\
\text { implicit racial attitudes and their } \\
\text { communication during simulated genetic } \\
\text { counseling sessions. }\end{array}$ & Yes & $\begin{array}{l}\text { Genetic counselors showed a moderate to strong } \\
\text { pro-White bias on the Race IAT. Counselors } \\
\text { with stronger pro-White bias tended to use less } \\
\text { emotionally responsive communication when } \\
\text { counseling minority simulated clients. }\end{array}$ \\
\hline $\begin{array}{l}\text { Rojas et al. } \\
2017 \text { [34] }\end{array}$ & $\begin{array}{l}\text { Racial implicit } \\
\text { bias }\end{array}$ & $\begin{array}{l}342 \text { pediatricians. To evaluate whether implicit } \\
\text { racial bias influences pediatricians' suspicion of } \\
\text { child abuse as measured by } 9 \text { injury vignettes. }\end{array}$ & No & $\begin{array}{l}\text { No statistically significant differences in } \\
\text { suspicion for an abuse-related injury based on } \\
\text { the race of the child. However, the study did not } \\
\text { test for physicians' implicit bias. }\end{array}$ \\
\hline $\begin{array}{l}\text { Sabin et al. } \\
2012 \text { [35] }\end{array}$ & $\begin{array}{l}\text { Racial implicit } \\
\text { bias }\end{array}$ & $\begin{array}{l}86 \text { academic pediatricians. To examine } \\
\text { association between pediatricians' attitudes } \\
\text { about race and treatment recommendations by } \\
\text { patients' race. }\end{array}$ & Yes & $\begin{array}{l}\text { Pediatricians' implicit attitudes about race affect } \\
\text { pain management. }\end{array}$ \\
\hline $\begin{array}{l}\text { Cooper et al. } \\
2012[36]\end{array}$ & $\begin{array}{l}\text { Racial implicit } \\
\text { bias }\end{array}$ & $\begin{array}{l}\text { Cross-sectional study; } 40 \text { primary care } \\
\text { clinicians and } 269 \text { patients. To seeassociations } \\
\text { of clinicians' implicit attitudes about race with } \\
\text { visit communication and patient ratings of care. }\end{array}$ & Yes & $\begin{array}{l}\text { Clinician implicit race bias and race and } \\
\text { compliance stereotyping are associated with } \\
\text { markers of poor visit communication and poor } \\
\text { ratings of care, particularly among Black patients. }\end{array}$ \\
\hline $\begin{array}{l}\text { Blair et al. } \\
2013 \text { [37] }\end{array}$ & $\begin{array}{l}\text { Racial implicit } \\
\text { bias }\end{array}$ & $\begin{array}{l}210 \text { physicians, } 2,908 \text { patients. To investigate } \\
\text { whether clinicians' explicit and implicit } \\
\text { ethnic/racial bias is related to Black and Latino } \\
\text { patients' perceptions of their care. }\end{array}$ & Yes & $\begin{array}{l}\text { Clinicians' implicit bias may jeopardize their } \\
\text { clinical relationships with Black patients, which } \\
\text { could have negative effects on other care } \\
\text { processes. }\end{array}$ \\
\hline $\begin{array}{l}\text { Haider et al. } \\
2015 \text { [38] }\end{array}$ & $\begin{array}{l}\text { Racial and } \\
\text { social class } \\
\text { bias }\end{array}$ & $\begin{array}{l}215 \text { physicians. To determine whether clinicians' } \\
\text { unconscious race and/or social class biases } \\
\text { correlate with patient management decisions. }\end{array}$ & No & $\begin{array}{l}\text { Unconscious implicit biases were present among } \\
\text { participants. No association between the IAT } \\
\text { scores and vignette-based clinical assessments. }\end{array}$ \\
\hline
\end{tabular}




\begin{tabular}{|c|c|c|c|c|}
\hline $\begin{array}{l}\text { Haider et al. } \\
2015 \text { [39] }\end{array}$ & $\begin{array}{l}\text { Racial and } \\
\text { social class } \\
\text { bias }\end{array}$ & $\begin{array}{l}245 \text { registered nurses. To find association } \\
\text { between racial and social class bias with } \\
\text { clinical decision making. }\end{array}$ & No & $\begin{array}{l}\text { Implicit association tests scores did not } \\
\text { statistically correlate with vignette-based clinical } \\
\text { decision making. }\end{array}$ \\
\hline $\begin{array}{l}\text { Stull et al. } \\
2013 \text { [40] }\end{array}$ & $\begin{array}{l}\text { Mental illness } \\
\text { bias }\end{array}$ & $\begin{array}{l}154 \text { Assertive Community Treatment (ACT) } \\
\text { staff. To examine implicit and explicit biases } \\
\text { among ACT staff and explore the extent to } \\
\text { which biases predicted the use of treatment } \\
\text { control mechanisms. }\end{array}$ & No & $\begin{array}{l}\text { Participants exhibited positive implicit attitudes } \\
\text { towards people with mental illness. }\end{array}$ \\
\hline $\begin{array}{l}\text { Dabby et al. } \\
2015 \text { [41] }\end{array}$ & $\begin{array}{l}\text { Mental illness } \\
\text { bias }\end{array}$ & 35 Psychiatry residents and 68 psychiatrists. & No & $\begin{array}{l}\text { Psychiatrists and residents did not harbor } \\
\text { negative implicit bias towards mental illness. }\end{array}$ \\
\hline $\begin{array}{l}\text { Teachman et } \\
\text { al. } 2001[42]\end{array}$ & $\begin{array}{l}\text { Weight or } \\
\text { anti-fat bias }\end{array}$ & $\begin{array}{l}84 \text { health professionals. To investigate whether } \\
\text { negative implicit attitudes and beliefs toward } \\
\text { overweight persons exist among health } \\
\text { professionals who specialize in obesity } \\
\text { treatment, and to compare these findings to the } \\
\text { implicit anti-fat bias. }\end{array}$ & Yes & $\begin{array}{l}\text { Even among health professionals who specialize } \\
\text { in obesity treatment, strong implicit anti-fat bias } \\
\text { was evident in evaluations of overweight persons } \\
\text { as bad and beliefs that overweight persons are } \\
\text { lazy. }\end{array}$ \\
\hline $\begin{array}{l}\text { Schwart et al. } \\
2003[43]\end{array}$ & $\begin{array}{l}\text { Weight or } \\
\text { anti-fat bias }\end{array}$ & $\begin{array}{l}389 \text { clinicians and researchers. To determine } \\
\text { the level of anti- fat bias in health professionals } \\
\text { specializing in obesity. }\end{array}$ & Yes & $\begin{array}{l}\text { Health professionals exhibited a significant } \\
\text { pro- thin, anti- fat implicit bias on the IAT. In } \\
\text { addition, the subjects significantly endorsed the } \\
\text { implicit stereotypes of lazy, stupid, and } \\
\text { worthless. }\end{array}$ \\
\hline $\begin{array}{l}\text { Sabin et al. } \\
2015 \text { [44] }\end{array}$ & $\begin{array}{l}\text { Weight or } \\
\text { anti-fat bias }\end{array}$ & $\begin{array}{l}134 \text { Indian Health Service (HIS) clinicians. To } \\
\text { explore association between weight and race } \\
\text { bias with treatment approach for obesity. }\end{array}$ & No & $\begin{array}{l}\text { Weight and race bias was found among long- } \\
\text { term IHS clinicians, but this did not influence } \\
\text { treatment approaches for overweight American } \\
\text { Indian/Alaska Native children. }\end{array}$ \\
\hline $\begin{array}{l}\text { Miller et al. } \\
2013 \text { [45] }\end{array}$ & $\begin{array}{l}\text { Weight or } \\
\text { anti-fat bias }\end{array}$ & $\begin{array}{l}\text { To determine the prevalence of weight-related } \\
\text { biases among medical students }(n=310) \text { and } \\
\text { whether they were aware of their biases. }\end{array}$ & Yes & $\begin{array}{l}33 \%(101 / 310) \text { self-reported a significant } \\
\text { ("moderate" or "strong") explicit anti-fat bias. } \\
\text { No students self-reported a significant explicit } \\
\text { anti-thin bias. According to the IAT scores, over } \\
\text { half of students had a significant implicit weight } \\
\text { bias: } 39 \%(121 / 310) \text { had an anti-fat bias and } \\
17 \%(52 / 310) \text { an anti-thin bias. Two-thirds of } \\
\text { students }(67 \%, 81 / 121) \text { were unaware of their } \\
\text { implicit anti-fat bias. }\end{array}$ \\
\hline
\end{tabular}




\begin{tabular}{|c|c|c|c|c|}
\hline $\begin{array}{l}\text { Phelan et al. } \\
2014 \text { [46] }\end{array}$ & $\begin{array}{l}\text { Weight or } \\
\text { anti-fat bias }\end{array}$ & $\begin{array}{l}\text { To examine the magnitude of explicit and } \\
\text { implicit weight biases and identify factors } \\
\text { predicting bias among } 1 \text { st year medical students } \\
(n=4,732) \text {. }\end{array}$ & Yes & $\begin{array}{l}\text { A large number of students exhibited implicit } \\
(74 \%) \text { and explicit }(67 \%) \text { weight bias. Explicit } \\
\text { attitudes were more negative toward obese } \\
\text { people than toward racial minorities, gays, } \\
\text { lesbians, and poor people. }\end{array}$ \\
\hline $\begin{array}{l}\text { Sabin et al. } \\
2012 \text { [47] }\end{array}$ & $\begin{array}{l}\text { Weight or } \\
\text { anti-fat bias }\end{array}$ & $\begin{array}{l}\text { 2,284 medical doctors. To examine implicit and } \\
\text { explicit attitudes about weight among MDs and } \\
\text { determine the pervasiveness of negative } \\
\text { attitudes about weight among MDs. }\end{array}$ & Yes & $\begin{array}{l}\text { Strong implicit and explicit anti-fat bias is as } \\
\text { pervasive among MDs as it is among the general } \\
\text { public. }\end{array}$ \\
\hline $\begin{array}{l}\text { Swift et al. } \\
2013[48]\end{array}$ & $\begin{array}{l}\text { Weight or } \\
\text { anti-fat bias }\end{array}$ & $\begin{array}{l}22 \text { intervention and } 21 \text { control trainee health } \\
\text { care professionals. Pilot a randomized } \\
\text { controlled trial of the effects of educational } \\
\text { films designed to reduce weight stigmatization } \\
\text { toward obese patients on trainee dietitians' and } \\
\text { doctors' attitudes. }\end{array}$ & Yes & $\begin{array}{l}\text { Participants demonstrated weight bias. The } \\
\text { intervention films significantly improved explicit } \\
\text { attitudes and beliefs toward obese people but did } \\
\text { not significantly improve implicit anti-fat bias. }\end{array}$ \\
\hline $\begin{array}{l}\text { Waller et al. } \\
2012 \text { [49] }\end{array}$ & $\begin{array}{l}\text { Weight or } \\
\text { anti-fat bias }\end{array}$ & 45 nursing and 45 psychology students. & Yes & $\begin{array}{l}\text { A statistically significant implicit bias was found } \\
\text { in both groups. }\end{array}$ \\
\hline $\begin{array}{l}\text { Rukavina et } \\
\text { al. } 2010 \text { [50] }\end{array}$ & $\begin{array}{l}\text { Weight or } \\
\text { anti-fat bias }\end{array}$ & $\begin{array}{l}\text { To assess the efficacy of a multi-component } \\
\text { intervention to reduce } \\
\text { Kinesiology pre-professionals' implicit and } \\
\text { explicit bias }(n=78) \text {. }\end{array}$ & Yes & $\begin{array}{l}\text { On the pre-test, participants did not display } \\
\text { overall explicit bias on the anti-fat attitudes test } \\
\text { (AFAT) but had strong implicit bias and bias on } \\
\text { the lazy/motivated semantic differential scale. }\end{array}$ \\
\hline $\begin{array}{l}\text { Phelan et al. } \\
2015 \text { [51] }\end{array}$ & $\begin{array}{l}\text { Weight or } \\
\text { anti-fat bias }\end{array}$ & $\begin{array}{l}1,795 \text { medical students surveyed at the } \\
\text { beginning of their } 1^{\text {st }} \text { year and end of their } 4^{\text {th }} \\
\text { year. To assess medical school factors that } \\
\text { influence change in implicit and explicit bias } \\
\text { against people with obesity. }\end{array}$ & Yes & $\begin{array}{l}\text { Increased implicit and explicit biases were } \\
\text { associated with less positive contact with patients } \\
\text { who have obesity and more exposure to faculty } \\
\text { role-modeling of discriminatory behavior or } \\
\text { negative comments about patients with obesity. } \\
\text { Increased implicit bias was associated with } \\
\text { training in how to deal with difficult patients. }\end{array}$ \\
\hline $\begin{array}{l}\text { Burke et al. } \\
2015 \text { [52] }\end{array}$ & $\begin{array}{l}\text { Sexual } \\
\text { orientation } \\
\text { bias }\end{array}$ & $\begin{array}{l}\text { Heterosexual first-year medical students }(n= \\
4,441) \text { were examined for both explicit and } \\
\text { implicit biases against lesbian women and gay } \\
\text { men among medical students, focusing on two } \\
\text { predictors of such bias, contact and empathy. }\end{array}$ & Yes & $\begin{array}{l}\text { Nearly half }(45.8 \%) \text { of the respondents had } \\
\text { some explicit bias and } 81.5 \% \text { had expressed } \\
\text { implicit bias against gay and lesbian individuals. } \\
\text { Both cognitive and emotional empathy predicted } \\
\text { positive explicit attitudes, but not implicit } \\
\text { attitudes. }\end{array}$ \\
\hline
\end{tabular}




\begin{tabular}{|c|c|c|c|c|}
\hline $\begin{array}{l}\text { Sabin et al. } \\
2015 \text { [53] }\end{array}$ & $\begin{array}{l}\text { Sexual } \\
\text { orientation } \\
\text { bias }\end{array}$ & $\begin{array}{l}\text { To examine attitudes toward heterosexual } \\
\text { people versus lesbian and gay people in } 2,338 \\
\text { medical doctors, } 5,379 \text { nurses, } 8,531 \text { mental } \\
\text { health providers, } 2,735 \text { other treatment } \\
\text { providers, and } 214,110 \text { non-providers in the } \\
\text { United States. }\end{array}$ & Yes & $\begin{array}{l}\text { Generally, implicit preferences always favored } \\
\text { heterosexual people over lesbian and gay people } \\
\text { among heterosexual providers. Heterosexual } \\
\text { nurses held the strongest implicit preference for } \\
\text { heterosexual men over gay men (Cohen } \mathrm{d}= \\
1.30 ; 95 \% \text { confidence interval }=1.28,1.32 \\
\text { among female nurses; Cohen } \mathrm{d}=1.38 ; 95 \% \\
\text { confidence interval }=1.32,1.44 \text { among male } \\
\text { nurses). }\end{array}$ \\
\hline $\begin{array}{l}\text { Ruiz et al. } \\
2015 \text { [54] }\end{array}$ & $\begin{array}{l}\text { Anti-aging } \\
\text { bias }\end{array}$ & $\begin{array}{l}\text { To assess medical students' explicit and implicit } \\
\text { anti-aging bias and their intent to practice with } \\
\text { older people in the future }(n=103) \text {. }\end{array}$ & Yes & $\begin{array}{l}\text { Explicit attitudes toward older people were } \\
\text { moderately positive. A majority of participants } \\
\text { (90\%) showed a preference for treatment of } \\
\text { younger than older people. Female medical } \\
\text { students demonstrated less ageist, anti-aging } \\
\text { bias, higher internal motivation, and stronger } \\
\text { intentions to practice with older people. }\end{array}$ \\
\hline $\begin{array}{l}\text { Penner et al. } \\
2016 \text { [55] }\end{array}$ & $\begin{array}{l}\text { Racial implicit } \\
\text { bias }\end{array}$ & $\begin{array}{l}18 \text { oncologists, } 112 \text { patients. To examine } \\
\text { whether oncologists' implicit bias negatively } \\
\text { affect communication and patient reactions to } \\
\text { recommended treatment. }\end{array}$ & Yes & $\begin{array}{l}\text { Oncologist implicit racial bias was associated } \\
\text { with less patient centered and supportive } \\
\text { communication, and less patient confidence in } \\
\text { treatment. }\end{array}$ \\
\hline $\begin{array}{l}\text { Blair et al. } \\
2013 \text { [56] }\end{array}$ & $\begin{array}{l}\text { Racial implicit } \\
\text { bias }\end{array}$ & $\begin{array}{l}\text { To assess implicit and explicit bias against } \\
\text { Latinos and African Americans among primary } \\
\text { care providers }(n=210) \text { and community } \\
\text { members }(n=190) \text {. }\end{array}$ & Yes & $\begin{array}{l}\text { Both primary care providers and community } \\
\text { members demonstrated substantial implicit bias } \\
\text { against both Latinos and African Americans. }\end{array}$ \\
\hline $\begin{array}{l}\text { van Ryn et al. } \\
2015 \text { [57] }\end{array}$ & $\begin{array}{l}\text { Racial implicit } \\
\text { bias }\end{array}$ & $\begin{array}{l}3,547 \text { medical students. To examine the effect } \\
\text { of medical education in changing students' } \\
\text { racial implicit bias. }\end{array}$ & Yes & $\begin{array}{l}\text { Medical school experience explored in the study } \\
\text { was independently associated with a change in } \\
\text { students' implicit bias. }\end{array}$ \\
\hline
\end{tabular}




\section{Mental Health}

Stull et al (2013) found that participants had implicit bias towards people with mental illness [40], while Dabby et al (2015) who measured implicit bias among psychiatrists and residents found no negative implicit bias towards patients with mental illness [41].

\section{Weight}

Eight studies measured weight implicit bias and found moderate to strongimplicit bias among participants [42-49]. Of the two studies that employed an intervention, the intervention did not significantly improve implicit weight bias $[48,50]$. One study conducted by Phelan et al (2015) [51] found evidence that medical school factors may influence weight implicit bias. Such medical school factors include: 1) The type of interaction medical students has had with overweight or obese patients during training, whether positive or negative, interacted with their weight implicit bias; 2) Medical students in training perceived obese patients to be 'difficult' to manage, because more time is spent treating them, even though the circumstances are that obese patients are likely to have many co-morbidities, hence, requiring more treatments; 3) The medical school disparity curriculum is focused on racial implicit bias, and much less on other kinds of biases; and 4) Working with senior medical colleagues and treating them as role models during clinical rotations make negative comments or show negative attitudes towards patients based on their weight among medical students [51].

\section{Sexual Orientation \& Aging}

Boysen \& Vogel (2008) measured race and sexual orientation bias and found implicit bias present towards African Americans, Lesbians and Gay men among the participants [2]. In both of the studies that examined implicit bias associated with sexual orientation, there were stronger implicit preferences for heterosexuals than Lesbians, and Gay, although the strength of association varied [52,53]. Ruiz et al (2015) showed that participants' implicit measure showed negativity towards the elderly, but there was no difference between the groups compared [54].

\section{Bias in Healthcare}

In an attempt to predict physicians' racial bias in the recommendation for thrombolysis in patients with acute coronary syndrome, three IATs were used: Race Preference IAT, Race Cooperativeness IAT, and Race Medical Cooperativeness IAT [10]. All three IATs showed significant racial bias. Physicians diagnosed more Blacks with coronary artery disease than White patients [10]. A similar study which measured implicit bias among physicians and people with terminal degrees found significant implicit bias especially among the female participants [25]. One study investigated the link between clinicians' unconscious attitudes concerning race with the physician-patient communication during clinic visits and patient ratings of care. In particular, they examined two implicit attitudes about race: general racial bias and racial bias regarding stereotyping patient compliance. Studies found that physicians' biases are associated with markers of poor visit communication and poor ratings of care, especially in Black patients [27]. Moskowitz et al (2012) observed that physicians stereotype certain diseases with Blacks. This suggests that diagnoses and treatment of Black patients may be biased [28].

The researchers focused on the following questions relating to the accessibility of healthcare professionals' stereotypes: 1) Are stereotypes made accessible without awareness whenever one person categorizes another as a member of a stereotyped group? 2) Does this unconscious event result in both the factual information associated with a group and the incorrect, undesired elements of the stereotype (which are explicitly rejected) attaining accessibility and heightened potential influence? This study concluded that diagnoses and treatment of African American patients may be biased implicitly. The conclusions from this study are similar to results from Green et al (2007), Blair et al (2013), Cooper et al (2012), and Penner (2016) $[10,36,55,56]$. However, in studies conducted by Oliver et al (2014), Blair et al (2014), and Rojas et al (2017), there were insufficient evidence to conclude that racial implicit bias of healthcare providers influenced the quality of care or clinical judgment, although implicit bias was present among participants $[27,32,34]$. 


\section{Types of Healthcare Personnel Measured}

About $64 \%$ of the studies measured implicit bias among medical doctors [10,26-32,34-37,41,42,44, 46,55-57], the rest included registered nurses $(11 \%)$, medical students $(20 \%)$, genetic counselors $(0.2 \%)$, research and health professionals $(0.8 \%)$ $[42,43]$, and pre-kinesiology students $(0.2 \%)$. Forty-two percent of the studies included specific medical specialties: internal medicine, primary care physicians, and emergency residents $[10,27$, $36,39,46]$. Five studies showed evidence on both health care providers and patients. Types of patients were: patients with hypertension or spinal cord injury, and patients of different races [29,32, $36,37,55]$. More than a quarter $(26 \%)$ of the study included participants who were students, the category of students being medical students, nursing students, psychology students, and masters level dietetic students $[30,34,45,48,49,51,52,54]$.

\section{Types of Measurement Tools Used \\ Implicit Association Test}

Thirty-three of the 35 articles (94\%) included in the review used IAT to measure implicit bias among the participants. Two of these was a penand-paper IAT [2], others were computer-based or online. The IATs varied by the type of implicit bias being measured. Two of the studies measured racial implicit bias using different methods such as Race preference IAT, Race Cooperativeness IAT, and Race Medical Cooperativeness IAT [10,27].

\section{Case study}

Nine $(26 \%)$ of the studies used case or clinical vignette [26,27,29,30,34,39,47]. One study used case vignette only, without the IAT, the rationale being that the latter is considered a non-blinded measure, and does not effectively measures behavior and clinical evaluation [34]. Another study used subliminal priming to measure implicit bias [28]. Another study had a pre-and post-test experimental design that used educational films as interventions and several measurements including IAT to compare the outcomes of the two groups [48]. Many of the studies in this review also measured explicit biases that are at conscious level and made on purpose, but information about explicit bias was not included in the scope of this review.

\section{Intersectionality}

Among the selected articles, 15 studies measured race/ethnicity implicit bias only; two studies focused on sexual orientation, two measured implicit bias of mental illness, ten examined weight (anti-fat) bias, while one article looked at antiaging implicit bias only. Among the studies which measured more than one type of implicit bias, four assessed implicit bias on race and social class, one study measured race and sexual orientation. The studies that measured more than one domain (e.g., race and sexual orientation) did so separately without investigating how the domains overlapped or interacted with each other.

\section{Discussion}

The studies included in this systematic review showed the outcome of six types of implicit bias such as race, weight or fat, social class, sexual orientation, mental illness, and aging. The outcome measurements were physician's clinical decision making, physician's preference for patients by race, doctor-patient communication, physician's treatment recommendation, physician's quality of care, and patient's perception of their care. Of the 35 studies reviewed, the majority $(n=24,68.6 \%)$ reported a positive adverse effect of bias on health outcome measurements. Two major biases identified in this study were race bias and weight or fat bias. These two biases, among others, could be considered major mediators of potential health disparities affecting the African American population in the United States.

According to U.S. Census Bureau 2016 estimate [58], the African American population are mostly distributed in District of Columbia (49\%), and in some southern states including Mississippi (38\%), Louisiana (34\%), Georgia (33\%), South Carolina (29\%), and Alabama (28\%). Likewise, some of the southern states including Mississippi (37.3\%), Oklahoma (36.5\%), Alabama (36.3\%), Louisiana (36.2\%), and Arkansas (35.0\%) are also ranked worst in terms of adult obesity rates in the country [59]. As a result of double whammy of having 
majority of Black population and the burden of obesity, these southern states are especially vulnerable to implicit bias in health care.

In our analysis, only $14 \%$ (5 of 35 ) of the studies reported more than one domain of implicit bias affecting a single entity, whereas the studies did not examine the intersectionality of the domains investigated. Although intersectionality has been widely studied in law, psychology and other fields, this topic has received little attention in public health, especially in identifying the contributions of intersecting implicit biases to health disparities [12]. It is known that social identities intersect, and this has the potential to influence individuals' life experiences, social interactions, and health status. Although some interlocking identities are favorable, the precept of intersectionality helps explain how neglect of overlapping social identities may translate into a health disparity. In a study, Bowleg (2012) identified intersectionality theory as an important theoretical framework for public health. The theory has the potential to enhance the precision of identifying marginalization, and developing intervention strategies with relevant outcomes [12,13].

In developing countries, such as Bangladesh, India, Malaysia, Nepal, and Pakistan, the problem of biases in healthcare services is often overlooked. In these societies, preference for a male child is near universal and utilization of health care is preferred for boys over girls. In a cross-sectional study of 3,100 families in a rural community in western India, significantly more boys than girls $(88.9 \%$ vs. $76.5 \%$, respectively) were given treatment by a registered medical practitioner (odds ratio, 2.51) [60]. Referrals for further treatment were followed by parents significantly more often for their sons than daughters (69.2\% vs. 25.0\%; OR 6.75). Similar bias toward preferential healthcare for males was observed in a treatment center in Bangladesh [61]. In-depth surveys of intra-family food distribution showed that males were given more calorie- and protein-rich foods compared with females of all ages, even when nutrient requirements due to varying body weight, pregnancy, lactation, and activity levels were considered [61]. Due to scarce of data, there is an urgent need of future research on the issue of intersectionality of biases based on religion, cast, ethnic minority, and economically marginalized population (especially landless impoverished villagers, and everexpanding urban slum dwellers) and their effects on the healthcare services in developing countries.

To measure the intersectionality of implicit bias or evaluate multiple domains of social identities, an appropriate measurement tool is essential. IAT is the most widely used tool for assessing implicit bias, while this instrument measures a broad range of biases, each independently. The Hierarchical Classes Analysis (HICLAS) and statistical methods such as regression analyses, ANOVA, and qualitative methods have been identified as novel approaches to measuring interactions and the intersectionality of multiple identities [16]. However, the results of these analyses do not seem to describe the intersectionality theory. Issues such as differences in terminology, the amount of value ascribed to each identity in order to have a true mathematical meaning and incorporating intersectionality to population health models are described by Bauer (2014) [18]. Future studies are needed to measure the multiplicative effects of several biases identified in a single health care entity.

The field of public health is inherently intersectional, which further emphasizes the need to employ multiple methods in the study of the intersectionality of implicit biases. The focus of implicit bias research has mostly been in a healthcare setting. Researches have also examined the effects of implicit bias on clinical judgment and its contribution to health disparities. It is high time that public health professionals focus on implicit bias within public health.

Finally, intersectionality presents the field of public health with a framework for addressing health disparities, considering the dearth of public health research that addresses the multiplicity of social identities [1]. Nevertheless, the benefits of studies of intersectionality are not without their own challenges. The challenges of intersectionality research include: a lack of precise methodology to study intersectionality; the difficulty in determining weight of all intersectional identities; whether to focus on intersectional identities or processes [1, 12]; and lack of evidence of appropriate statistical methods in measuring the intersectionality of multiple identity. 
Public Health Implications

1. The theory of intersectionality has not exhausted its movement. To further understand the relationships between implicit bias towards individuals based on their identities, and health disparity, the application of the intersectionality may provide new insight.

2. The IAT has been well received in many fields of academia. It has been used by hundreds of studies and programs to measure implicit bias. However, the present IAT seem largely insufficient to measure the intersectionality of these biases. Hence, to fully explore these, a measurement tool that fulfills this need must be developed.

3. Within the last decade, there has been an avalanche of studies programs and interventions aimed at mitigating health disparity. An interesting dimension would be studies that examine the intersectionality of these determinants of health, and how much the multiplicative effects contribute to health disparity and its effects on the health status of the population.

4. The theory of intersectionality is similar to the theory behind the epidemiological and statistical procedure of effect modification using the multiplicative model. An exploration of the similarities between these should be explored, and the results would be instrumental in understanding and designing interventions directed at health disparity in public health.

\section{Conclusions}

Intersectionality promises to be useful in understanding the interactions and complexities of social determinants of health, health disparities, and the effects of the multiplicities of various forms of implicit biases. This review shows a research gap of not measuring the multiplicative effects of implicit biases in public health. Intersectionality studies have several challenges, but it continues to evolve and should be explored by public health researchers and professionals.

\section{Acknowledgements}

The authors acknowledge the Jackson State University librarians who assisted with the identification of databases and the in-depth literature search.

\section{Authors' contributions}

OO collected data, wrote the initial draft, and revised the manuscript; AKM developed the concept, supervised the study, and edited the manuscript; and JKR developed the concept, collected data, and critically reviewed the manuscript.

Conflict of Interest: The authors declare no conflict of interest.

\section{References}

1. Bowleg L. When black + lesbian + woman $\neq$ black lesbian woman: The methodological challenges of qualitative and quantitative intersectionality research. Sex Roles. 2008; 59(5-6): 312-325.

2. Boysen GA, Vogel DL.The relationship between level of training, implicit bias, and multicultural competency among counselor trainees. Training Educ Professional Psychol. 2008; 2(2): 103-110.

3. Carbado DW, Crenshaw KW, Mays VM, Tomlinson B. INTERSECTIONALITY: Mapping the movements of a theory. Du Bois Rev. 2013; 10(2): 303-312.

4. Hull GT, Bell-Scott P, Smith B (eds). All the women are white, all the blacks are men: But some of us are brave. Black women's studies. Second edition. The Femnist Press, 1991.

5. Crenshaw K. Demarginalizing the intersection of race and sex: A black feminist critique of antidiscrimination doctrine, feminist theory and antiracist politics. Univ Chicago Legal Forum. 1989.

6. Blair IV, Banaji MR. Automatic and controlled processes in stereotype priming. J Personality Soc Psychol. 1996; 70(6): 1142-1163. 
7. Fazio RH, Jackson JR, Dunton BC, Williams CJ. Variability in automatic activation as an unobtrusive measure of racial attitudes: A bona fide pipeline? J Personality Soc Psychol. 1995; 69(6): 1013-1027.

8. Devine PG. Stereotypes and prejudice: Their automatic and controlled components. J Personality Soc Psychol. 1989; 56(1): 5-18.

9. Greenwald AG, Banaji MR. Implicit social cognition: Attitudes, self-esteem, and stereotypes. Psychol Rev. 1995; 102(1): 4-27.

10. Green AR, Carney DR, Pallin DJ, et al. Implicit bias among physicians and its prediction of thrombolysis decisions for black and white patients. J Gen Int Med. 2007; 22(9): 1231-1238

11. Williams JC. Double jeopardy? An empirical study with implications for the debates over implicit bias and intersectionality. Harvard $J$ Law Gender. 2014; 37(1): 185-242.

12. Bowleg L. The problem with the phrase women and minorities: Intersectionality - an important theoretical framework for public health. Am J Public Health. 2012; 102(7): 1267-1273.

13. Chappell NL, Havens B. Old and female: Testing the double jeopardy hypothesis. Sociological Quart. 2016; 21(2): 157-171.

14. Parks GS, Rachlinski JJ. Unconscious bias and the 2008 presidential election. Cornell Law Faculty Publications. Paper 95, 2008.

15. Moher D, Liberati A, Tetzlaff J, Altman DG. The PRISMA Group. Preferred reporting items for systematic reviews and metaanalyses: The PRISMA statement. PLoS Med. 2009; 6(7): e1000097.

16. Stirratt MJ, Meyer IH, Ouellette SC, Gara MA. Measuring identity multiplicity and intersectionality: Hierarchical Classes Analysis (HICLAS) of sexual, racial, and gender identities. Self and Identity. 2008; 7(1): 89-111.

17. Covarrubias A. Quantitative intersectionality: A critical race analysis of the Chicana/o educational pipeline. J Latinos Edu. 2011; 10(2): 86-105.

18. Bauer GR. Incorporating intersectionality theory into population health research methodology: Challenges and the potential to advance health equity. Soc Sci Med. 2014; 110: 10-17.
19. Dubrow J. Why should we account for intersectionality in quantitative analysis of survey data? In: Kallenberg V, Meyer J, Müller JM (Eds.). Intersectionality und Kritik. Springer Fachmedien Wiesbaden, 2013: 161-177.

20. Garnett BR, Masyn KE, Austin SB, Miller M, Williams DR, Viswanath K. The intersectionality of discrimination attributes and bullying among youth: An applied latent class analysis, $J$ Youth Adoles. 2014; 43(8): 1225-1239.

21. Hancock AM. When multiplication doesn't equal quick addition: Examining intersectionality as a research paradigm. Perspectives Politics. 2007; 5(1): 63-79.

22. McCall L. The Complexity of Intersectionality. Signs. 2005; 30(3): 1771-1800.

23. Witteloostuijn AO van. Applying intersectionality as a method. A critical analysis of how to apply feminist and intersectional methodologies in qualitative research.Utrecht University, 2018, Faculty of Humanities Thesis.

24. Hunting G. Intersectionality-informed qualitative research: A primer. Institute for Intersectionality Research and Policy, Simon Fraser University, British Columbia, Canada. 2014.

25. Sabin JA, Nosek BA, Greenwald AG, Rivara FP. Physicians' implicit and explicit attitudes about race by MD race, ethnicity, and gender. $J$ Health Care Poor Underserved. 2009; 20(3): 896-913.

26. Puumala SE, Burgess KM, Kharbanda AB, et al. The role of bias by emergency department providers in care for American Indian children. Med Care. 2016; 54(6): 562-569.

27. Oliver MN, Wells KM, Joy-Gaba JA, Hawkins CB, Nosek BA. Do physicians' implicit views of African Americans affect clinical decision making? J Am Board Fam Med. 2014; 27(2): 177-188.

28. Moskowitz GB, Stone J, Childs A. Implicit stereotyping and medical decisions: Unconscious stereotype activation in practitioners' thoughts about African Americans. Am J Public Health. 2012; 102(5): 996-1001.

29. Hausmann LRM, Myaskovsky L, Niyonkuru $\mathrm{C}$, et al. Examining implicit bias of physicians 
who care for individuals with spinal cord injury: A pilot study and future directions. $J$ Spinal Cord Med. 2015; 38(1): 102-110.

30. Haider AH, Sexton J, Sriram N, et al. Association of unconscious race and social class bias with vignette-based clinical assessments by medical students. $\mathrm{J}$ Am Med Assoc. 2011; 306(9): 942-951.

31. Haider AH, Schneider EB, Sriram N, et al. Unconscious race and class bias: Its association with decision making by trauma and acute care surgeons. J Trauma Acute Care Surg. 2014; 77(3): 409-416.

32. Blair IV, Steiner JF, Hanratty R, et al. An investigation of associations between clinicians' ethnic or racial bias and hypertension treatment, medication adherence and blood pressure control. J Gen Int Med. 2014; 29(7): 987-995.

33. Schaa KL, Roter DL, Biesecker BB, Cooper LA, Erby LH. Genetic counselors' implicit racial attitudes and their relationship to communication. Health Psychology. 2015; 34(2): 111-119.

34. Rojas M, Walker-Descartes I, Laraque-Arena D. An experimental study of implicit racial bias in recognition of child abuse. Am J Health Behav. 2017; 41(3): 358-367.

35. Sabin JA, Greenwald AG. The influence of implicit bias on treatment recommendations for 4 common pediatric conditions: Pain, urinary tract infection, attention deficit hyperactivity disorder, and asthma. Am J Public Health. 2012; 102(5): 988-995.

36. Cooper LA, Roter DL, Carson KA, et al. The Associations of clinicians' implicit attitudes about race with medical visit communication and patient ratings of interpersonal care. Am J Public Health. 2012; 102(5): 979-987.

37. Blair IV, Steiner JF, Fairclough DL, et al. Clinicians' implicit ethnic/racial bias and perceptions of care among Black and Latino patients. Annals Fam Med. 2013; 11(1): 43-52.

38. Haider AH, Schneider EB, Sriram N, et al. Unconscious race and social class bias among acute care surgical clinicians and clinical treatment decisions. JAMA Surgery. 2015; 150(5): 457-464.
39. Haider AH, Schneider EB, Sriram N, et al. Unconscious race and class biases among registered nurses: Vignette-based study using implicit association testing. $J$ Am College Surgeons. 2015; 220(6): 1077-1086.e1073.

40. Stull LG, McGrew JH, Salyers MP, AshburnNardo L. Implicit and explicit stigma of mental illness: Attitudes in an evidence-based practice. J Nervous Mental Dis. 2013; 201(12): 1072-1079.

41. Dabby L, Tranulis C, Kirmayer LJ. Explicit and implicit attitudes of Canadian psychiatrists toward people with mental illness.Canadian $J$ Psychiatry. 2015; 60(10): 451-459.

42. Teachman BA, Brownell KD. Implicit anti-fat bias among health professionals: Is anyone immune? Int $J$ Obes Related Metabolic Disorders. 2001; 25(10): 1525-1531.

43 .Schwartz MB, Chambliss HO, Brownell KD, Blair SN, Billington C. Weight bias among health professionals specializing in obesity. Obesity Res. 2003; 11(9): 1033-1039.

44. Sabin JA, Moore K, Noonan C, Lallemand O, Buchwald D. Clinicians' implicit and explicit attitudes about weight and race and treatment approaches to overweight for American Indian children. Childhood Obesity. 2015; 11(4): 456-465.

45. Miller Jr DP, Spangler JG, Vitolins MZ, et al Are medical students aware of their antiobesity bias? Acad Med. 2013; 88(7): 978982.

46. Phelan SM, Dovidio JF, Puhl RM, et al. Implicit and explicit weight bias in a national sample of 4,732 medical students: The medical student CHANGES study. Obesity (Silver Spring). 2014; 22(4): 1201-1208.

47. Sabin JA, Marini M, Nosek BA. Implicit and explicit anti-fat bias among a large sample of medical doctors by BMI, race/ethnicity and gender. PLoS One. 2012; 7(11): e48448.

48. Swift JA, Tischler V, Markham S, et al. Are anti-stigma films a useful strategy for reducing weight bias among trainee healthcare professionals? Results of a pilot randomized control trial. Obesity Facts. 2013; 6(1): 91-102. 
49. Waller T, Lampman C, Lupfer-Johnson G. Assessing bias against overweight individuals among nursing and psychology students: An implicit association test. J Clin Nurs. 2012; 21: 3504-3512.

50. Rukavina PB, Li W, Shen B, Sun H. A service learning based project to change implicit and explicit bias toward obese individuals in kinesiology pre-professionals. Obesity Facts. 2010; 3(2): 117-126.

51. Phelan SM, Puhl RM, Burke SE, et al. The mixed impact of medical school on medical students' implicit and explicit weight bias. Med Educ. 2015; 49(10): 983-992.

52. Burke SE, Dovidio JF, Przedworski JM, et al. Do contact and empathy mitigate bias against gay and lesbian people among heterosexual first-year medical students? A report from the medical student CHANGE study. Acad Med. 2015; 90(5): 645-651.

53. Sabin JA, Riskind RG, Nosek BA. Health care providers' implicit and explicit attitudes toward lesbian women and gay men. $\mathrm{Am} \mathrm{J}$ Public Health. 2015; 105(9): 1831-1841.

54. Ruiz JG, Andrade AD, Anam R, et al. Groupbased differences in anti-aging bias among medical students. Gerontol Geriatrics Educ. 2015; 36(1): 58-78.
55. Penner LA, Dovidio JF, Gonzalez R, et al. The effects of oncologist implicit racial bias in racially discordant oncology interactions. $J$ Clin Oncol. 2016; 34(24): 2874-2880.

56. Blair IV, Havranek EP, Price DW, et al. An assessment of biases against Latinos and African Americans among primary care providers and community members. $A m J$ Public Health. 2013; 103(1): 92-98.

57. van Ryn M, Hardeman R, Phelan SM, et al. Medical school experiences associated with change in implicit racial bias among 3547 students: A medical student CHANGES study report. J Gen Int Med. 2015; 30(12): 1748-1756.

58. U.S. Census Bureau 2016 Estimate. African American Population by State.

59. Robert Wood Johnson Foundation. The state of obesity. Adult obesity rate by state, 2017 .

60. Ganatra B, Hirve S. Male bias in health care utilization for under-fives in a rural community of western India. Bull WHO. 1994; 72(1): $101-104$

61. Chen LC, Huq E, D'Souza S. Sex bias in the family allocation of food and health care in rural Bangladesh. Pop Develop Rev. 1981; 7(1): $55-70$ 